\title{
REDESIGNING POST-GRADUATE COURSES FOR FUTURE MUSEUM EDUCATORS IN TIME OF A PANDEMIC: AN EXPERIENCE FROM UNIVERSITY ROMA TRE
}

Antonella Poce, University of Modena and Reggio Emilia, Maria Rosaria Re, Mara Valente, University Roma Tre, Italy, Francesca Amenduni, Eidgenössisches Hochschulinstitut für Berufsbildung, Swiss

\section{Abstract}

The present paper aims to illustrate the reorganization of the second year course "Standards for museum education" of the two-year post-graduate course "Advanced Studies in Museum Education" promoted by the CDM (Museum Education Centre) - Dept. of Education at University Roma Tre, that was carried out during the Covid-19 pandemic, and to analyse the educational strategies adopted in terms of museum educators' professional development to face the 2020 Covid-19 lockdown of Italian museums and universities. The results, taking into consideration the activities and digital tools proposed, show in university students the efficacy of the course reorganization, in terms of transverse and professional skills development, critical thinking and collaboration in particular. Moreover, the data analysis offers useful indications in terms of university online lectures, e-learning laboratory activities and practices, evaluation tools and methodologies aimed at promoting professional development of in-training museum educators in a university learning context.

\section{Introduction}

The Creative Industries Education context, such as museums, galleries, and libraries, presents a low emphasis on the use of new digital technologies, entrepreneurship promotion, digital abilities and transverse skills development (Poce, 2019; European Commission, 2017). Both newly graduates and existing employees, especially adult professionals, in fact, lack fundamental skills (OECD, 2018) for their future careers, consequently having less opportunities to improve their development and to add new forms of digital expression to their work (European Commission, 2018). However, the use of web, mobile, social, and analytical tools is becoming more and more popular in the field of Cultural and Creative Industries. These communication channels proved to be essential for cultural institutions in general, and museums in particular, to face the challenges posed 
Poce, A., Re, M. R., Valente, M., \& Amenduni, F.

Redesigning Post-Graduate Courses for Future Museum Educators in Time of a Pandemic: An Experience from University Roma Tre

by the current world-wide health emergency. In a report published on the EUR LEX website, the need for stronger partnerships between the cultural and creative sectors, social partners and education and training providers, both through initial training and continuous professional development was highlighted. Such closer connections should provide these sectors with the combination of skills needed for creative entrepreneurship in a rapidly changing environment.

\section{The research context}

Considering the above conditions, the CDM (Centre for Museum Studies) - based at Dept. of Education of University Roma Tre - has designed and provided a revised version of the second-year course "Standards for museum education" of the two-year post-graduate course aimed at the professional development of future Museum Educators, offered in a blended teaching mode (face-to-face - $\mathrm{f} 2 \mathrm{f}$ - and online) on a dedicated platform.

The biennial course "Advanced Studies in Museum Education" is addressed to those interested in deepening the museum education theoretical references and those who wish to employ educational research methods in such a context: to analyse various categories of visitors' needs and to train on standards in museum education, that are set according to the results of the latest international research in the field. The course provides an international dimension to all its initiatives. Experts from the museum education field teach f2f classes (UCL, Loughborough Univ., Tate Modern, National Gallery - UK; Sorbonne - Fr; ICOM; Universidade Aberta - P; UNED, Murcia Univ. - SP; Smithsonian USA). An academic year involved about 294 hours of f2f lessons, 217 hours of e-learning via the orbisdictus.it platform, 206 hours of internships and project works, 33 hours of guided visits and 750 hours of self-study. In terms of distance learning, online activities were divided into theoretical and multimedia teaching units, with assessments and educational support from teachers. Internship activities took place at partner companies (e.g. MOMa S.p.a. and CoopCulture) or at public or private museums in Italy and abroad (Poce \& Iovine, 2015).

\section{Methodology}

From the beginning of March 2020, the spread of COVID-19 imposed an immediate reorganization of the post-graduate course. Even before the emergency, it was designed to promote students' digital, transverse and entrepreneurial skills. The mobilization of the world of culture - in particular of the one of cultural heritage - further encouraged the post-graduate course managing staff to create specific online teaching units aimed at understanding the current state of cultural heritage institutions and at figuring out which educational activities could have been effective for heritage institutions going massively 
Poce, A., Re, M. R., Valente, M., \& Amenduni, F.

\section{Redesigning Post-Graduate Courses for Future Museum Educators in Time of a Pandemic: An Experience from University Roma Tre}

online. The implementation and adaptation of the course contents were carried out together with the readjustment of the e-learning platform normally used for distance learning.

The VLE was re-designed to host a new section entirely dedicated to "extra" activities planned to deal with the emergency (see Table 1).

Table 6: $\quad$ Online activities to face the COVID-19 emergency within the post-graduate course

\begin{tabular}{|c|c|c|}
\hline $\begin{array}{l}\text { Enhanced online activities after } \\
\text { the COVID- } 19\end{array}$ & Institutions involved & Methodologies and tools \\
\hline $\begin{array}{l}\text { Videos with constant updatings } \\
\text { on the course schedule }\end{array}$ & University Roma Tre & e-learning video-recordings \\
\hline $\begin{array}{l}\text { Video-interviews with } \\
\text { entrepreneurial stakeholders } \\
\text { (Museum, galleries and other Cls) }\end{array}$ & $\begin{array}{l}\text { Italian Creative Industries } \\
\text { stakeholders (Teleskill, Links, } \\
\text { BSDesign, L'Erma, Eulotech, ETT) }\end{array}$ & e-learning video-recordings \\
\hline $\begin{array}{l}\text { Virtual Hands-on learning } \\
\text { activities }\end{array}$ & UCL ARENA (UK) & $\begin{array}{l}\text { e-learning, cooperative learning, } \\
\text { group discussions and } \\
\text { presentations. }\end{array}$ \\
\hline $\begin{array}{l}\text { New online module: } \\
\text { - Cultural heritage education } \\
\text { in the digital era; } \\
\text { - } \quad \text { How can museums become } \\
\text { more entrepreneurial } \\
\text { during the times of COVID- } \\
\text { 19; } \\
\text { - How Italian museums } \\
\text { provide virtual support to } \\
\text { schools; } \\
\text { Building relationships } \\
\text { through heritage } \\
\text { - Educational research } \\
\text { methodology } \\
\text { - Museums and social } \\
\text { networks }\end{array}$ & $\begin{array}{l}\text { University of Graz; University of } \\
\text { Prague, John Hopkins University; } \\
\text { National Lottery Heritage } \\
\text { Fund(UK); University Roma Tre }\end{array}$ & $\begin{array}{l}\text { e-learning, cooperative learning, } \\
\text { group discussions and } \\
\text { presentations, OERs, project- } \\
\text { based learning, problem based- } \\
\text { learning, Social Networks. }\end{array}$ \\
\hline $\begin{array}{l}\text { Online internship and training } \\
\text { activities: Design thinking and } \\
\text { service design }\end{array}$ & University Roma Tre & $\begin{array}{l}\text { e-learning, OERs, project-based } \\
\text { learning, problem based-learning }\end{array}$ \\
\hline External MOOC & $\begin{array}{l}\text { OpenVM Erasmus+ project, } \\
\text { DigiCulture Erasmus+ project; } \\
\text { National Gallery Washington }\end{array}$ & $\begin{array}{l}\text { e-learning, forums, OERs, textual } \\
\text { resources, webinars. }\end{array}$ \\
\hline
\end{tabular}

The materials shared in the Orbis Dictus VLE are OERs which are considered powerful educational tools for various reasons: in our case, students and teachers can use these online resources without any cost or limit (Poce, Agrusti, \& Re, 2015). OERs include periodically updated PDF files, streaming videos, apps, podcasts, assessment tests, quizzes, etc. available to students on the e-learning platform. A section of the VLE has been reserved for video-updates where students are periodically informed about the activities progress and how to proceed in the course completion. Another large section has been devoted to 
Poce, A., Re, M. R., Valente, M., \& Amenduni, F.

\section{Redesigning Post-Graduate Courses for Future Museum Educators in Time of a Pandemic: An Experience from University Roma Tre}

video-interviews with stakeholders working in the field of new technologies for the fruition of cultural heritage, museum services, and specialized publishing. The video contributions of experts have represented a resource of primary importance, as they created new chances of interaction and cooperation between students and Creative Industries, partner institutions of the course. As far as f2f teaching and learning is concerned, national and international experts and teachers involved in the post-graduate course training activities agreed in redesigning conventional lectures and adapting them to the new digital educational context, meeting the challenge and collaborating to outline redesigned online programs (see Table 2). The students interested in attending one of the modules proposed by the experts were involved according to the following model: introduction of the activity, presentation of the issue, task description and live sessions to discuss and elaborate on the topic. Students were in fact invited to join a virtual classroom on Microsoft Teams $\subset$ and to participate in live sessions where group discussions, tasks performances, group activities and presentations were held.

Table 2: $\quad$ New modules and activities introduced in the e-learning mode

\begin{tabular}{|c|c|c|}
\hline Title & Acronym & Introduction \\
\hline $\begin{array}{l}\text { Virtual Hands-on learning } \\
\text { activities }\end{array}$ & $\mathrm{OBL}$ & $\begin{array}{l}\text { Theoretical and practical lessons on object-based learning } \\
\text { methodology }\end{array}$ \\
\hline $\begin{array}{l}\text { Cultural heritage education } \\
\text { in the digital era }\end{array}$ & CHDE & $\begin{array}{l}\text { Studying interactions between museums and social media } \\
\text { users to understand the relationship between museums and } \\
\text { digital audience and improve online communication }\end{array}$ \\
\hline $\begin{array}{l}\text { How can museums become } \\
\text { more entrepreneurial during } \\
\text { the times of COVID-19 }\end{array}$ & MME & $\begin{array}{l}\text { Strategies to make museums more entrepreneurial at the time } \\
\text { of a pandemic }\end{array}$ \\
\hline $\begin{array}{l}\text { How Italian museums } \\
\text { provide virtual support to } \\
\text { schools }\end{array}$ & MVSS & $\begin{array}{l}\text { In-depth studies and case studies on what kind of support } \\
\text { museums can offer to Italian schools in the educational field } \\
\text { and in the use of new digital technologies }\end{array}$ \\
\hline $\begin{array}{l}\text { Building relationships } \\
\text { through heritage }\end{array}$ & $\mathrm{BRH}$ & $\begin{array}{l}\text { The role of museums and heritage in supporting communities } \\
\text { by building social capital and cohesion within the Covid19 } \\
\text { pandemic context }\end{array}$ \\
\hline $\begin{array}{l}\text { Educational research } \\
\text { methodology }\end{array}$ & ERM & $\begin{array}{l}\text { The main methodological research guidelines in the } \\
\text { educational field. Providing knowledge about the creation and } \\
\text { use of the main tools for data collection in the museum } \\
\text { didactics field as well }\end{array}$ \\
\hline $\begin{array}{l}\text { Museums and Social } \\
\text { Networks }\end{array}$ & $M \& S N$ & $\begin{array}{l}\text { Deeply investigating the activities of three selected museums } \\
\text { on social networks during the Covid- } 19 \text { pandemic to plan an } \\
\text { educational-didactic activity to accompany the museum } \\
\text { chosen out of the three in being spread through social } \\
\text { networks. }\end{array}$ \\
\hline
\end{tabular}

Above all, a new perspective of the post-graduate course aimed at enhancing awareness and reflection on cultural heritage fruition and communication, as imposed by the ongoing pandemic, was promoted.

The renewed e-learning teaching modules offered a stronger possibility for the students to continue the undertaken path without interruptions or program changes. All the activities 
Poce, A., Re, M. R., Valente, M., \& Amenduni, F.

Redesigning Post-Graduate Courses for Future Museum Educators in Time of a Pandemic: An Experience from University Roma Tre

planned during the health emergency, as well as the live lessons, have been made optional, so that students were free to choose the courses that sparked more their interest and to carry out the activities that caught their attention the most.

The didactic modules carried out in e-learning, as mentioned above, consisted for a part of the study of materials provided by the teachers, proposals of practical activities usually organized in small groups through the use of online sharing and discussion platforms, and a live lesson by the teacher in which the theoretical subjects were further elaborated and the activities carried out by each group were discussed. The teachers gave their feedback on the work of the groups at the end of the live session, highlighting the positive aspects and pointing out what needed to be reviewed or modified; a Q\&A session was planned for the last part of every lesson, in which, through questions asked to the professors, any doubt was clarified, and any in-depth analysis of the most interesting aspects was explored.

\section{Data collection and data analysis}

The main aim of the learning experience here presents is finding out how the kind of activities mentioned above could encourage 4C skills development, promoting teamwork and Cooperation, Creativity, Critical Thinking, and Communication among students. The post-graduate course managing staff and lecturers involved in the learning activities have designed the evaluation plan of the objectives achieved by the participating students as follows.

- Formative assessment activities: during the course, different assessment tools are used to monitor the level of knowledge acquisition and the transverse skills development. Two evaluation tools are used for formative assessment: a selfassessment survey of the skills developed (consisting of both open-ended and closed questions), filled in by the students at the end of each teaching module, and a closed-ended evaluation test to assess the level of knowledge acquired. The results of the self-assessment survey will be analysed through automatic qualitative and quantitative analysis programs, while the results of the closed-ended evaluation test will be analysed through statistical analysis tools.

- Summative assessment activities: students are asked to produce an empirical research project in the field of museum mediation and cultural heritage fruition. The research product was assessed by a group of lecturers and tutors of the course through a Critical Thinking Evaluation Rubric, already used and validated in previous research (Poce, 2017). The rubric is applied to see whether Critical Thinking skills improve. Moreover, a final evaluation survey of the course will be filled in by the students to evaluate the general course progress, the specific educational activities, and the tools and teaching methodologies used. 
Poce, A., Re, M. R., Valente, M., \& Amenduni, F.

Redesigning Post-Graduate Courses for Future Museum Educators in Time of a Pandemic: An Experience from University Roma Tre

\section{Results}

- The group of students who took part in the learning experience attend the second year "Standards for museum education" of the two-year post-graduate course "Advanced Studies in Museum Education" at the University Roma Tre, Department of Education. In total, there are 17 students attending the second year of the postgraduate course. Of these, only 1 is a male student, while the rest is all female. The average age of the students is 30 years old and almost all of them have a master's degree in Art, while just a few of them are graduates in Archaeology or Pedagogical sciences.

The first module Virtual Hands-on learning activities (OBL) was attended by a total of 13 students, like the second one, Cultural heritage education in the digital era (CHDE); the third module, How can museums become more entrepreneurial during the times of COVID19 (MME), and the fourth one, How Italian museums provide virtual support to schools (MVSS), were attended by 9 students; the fifth module, Building relationships through heritage (BRH), was attended by 8 students; the sixth module Educational research methodology (ERM) was attended only by 1 student and the seventh module Museum and Social Networks (M\&SN) was attended by 2 students. In addition to the feedback received from the teachers during the live session, students expressed their opinion about the activities and lessons through a self-assessment survey. From the results visible in the Figure 1, all the activities were judged in a generally positive way by the students.

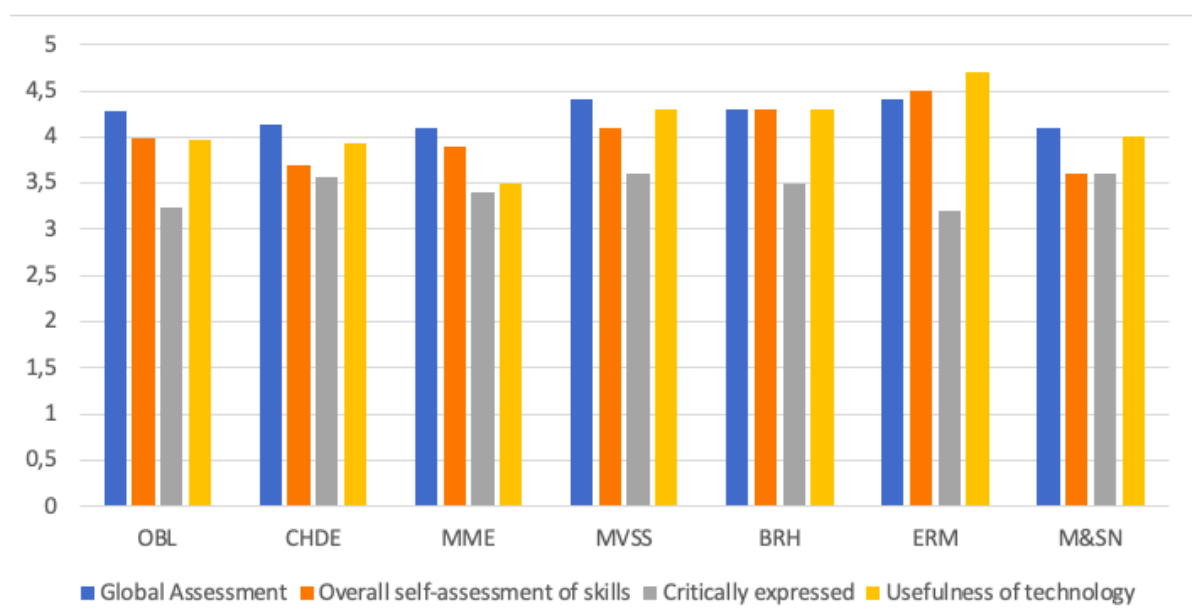

Figure 5. Evaluation results of course modules

With regards to the proposed activities' contents quality evaluation, it has registered most of the times, on a scale from 1 to $5(1=$ lowest quality; $5=$ highest quality), a score equal to or higher than 4, highlighting therefore that the proposed modules have transmitted easily comprehensible contents, with a high relevance to the themes and objectives of the postgraduate course, a clear structure, contents and language used by the teachers, with an 
Poce, A., Re, M. R., Valente, M., \& Amenduni, F.

Redesigning Post-Graduate Courses for Future Museum Educators in Time of a Pandemic: An Experience from University Roma Tre

average level of difficulty attributed to the assignments and activities the students have carried out in groups; the clearness, exhaustiveness and effectiveness that distinguished the contents and documents used during the lessons were also judged highly.

Regarding the self-assessment of the acquired knowledge, the students stated with a medium-high score that they learned what they expected from the lessons. Their expectations were met through mostly gradual learning: they easily understood the activities assigned to them and the tasks that had to be carried out. As to the information shared by the teachers, it was perceived as adequately delivered and mostly not taken for granted, with the amount of content always proportioned to the lesson. The students also considered the lessons, and in particular the topics dealt with, so interesting as to encourage them to carry out further in-depth studies on the subject.

Analysing the increase of transverse skills, considered one of the main aims of the course, the most solicited skills have been: Creativity, Innovation, Communication, Critical Thinking, Attitude to Research and Collaboration. The students had a medium-high increase in the Problem-solving skill, Memory and Entrepreneurship. On a scale from 1 to 5 , the average scores assigned to the activities have almost always exceeded the value of 4 , thus attributing a much more than favourable judgement to them.

Concerning the self-assessment survey data, the use of technology, according to the students' opinion, has significantly increased motivation and personal involvement, greatly facilitating the collaborative and participatory aspects of teaching, considerably increasing the confidence with technological tools, thus improving the quality of online teaching thanks to the daily use of new tools and VLE, that support and facilitate the sharing of materials with other colleagues.

\section{Discussion and conclusive remarks}

The use of web, mobile, social and media tools proved to be essential for cultural institutions in general and museums in particular to face the challenges posed by the current world-wide health emergency. Thus, future museum educators need to develop a critical approach towards the use of digital mediation and communication tools in order to creatively adopt them in the museum learning path, including university museum exhibitions.

The present research has shown how, thanks to the critical use of technological and digital supports, it has been possible to entirely reorganize the activities of the second year of a biennial post-graduate course that normally includes face-to-face lectures, laboratory activities and practices at the museum. Everything has been made possible smoothly from 
Poce, A., Re, M. R., Valente, M., \& Amenduni, F.

Redesigning Post-Graduate Courses for Future Museum Educators in Time of a Pandemic: An Experience from University Roma Tre

home thanks to the infinite possibilities offered by the internet and in particular by the digital resources made available by museums. It is no coincidence that, just to mention an example, in the Virtual Hands-on learning activities module, the Object based virtual learning activities were made possible thanks to the use of the digital objects collection made available by the Patrie Museum of the University College of London.

Given the overall very encouraging results, especially if we take into consideration the evaluations given by the students themselves, it is possible to rethink a reorganization of the course that involves both in presence and at distance activities, that we plan to concretely experiment next autumn. It is surely necessary to promptly review the possibility of increasing the number of laboratory activities in e-learning, which have proved to be the most requested by the students. The same goes for encouraging critical reflection activities, maybe through collaborative project proposals linked to concrete and current scenarios, to be submitted periodically to the students, thus stimulating Collaboration, Entrepreneurship and Problem-solving skills that, according to the students themselves, should be strengthened.

\section{Authors' statement}

The authors of the present paper contributed to the writing of this article as follows: A. Poce (Introduction, The research context, Discussion and conclusive remarks), M. R. Re (Methodology), M. Valente (Results), F. Amenduni (Data collection and data analysis).

\section{References}

European Commission (2017). Europe’s Digital Progress Report EDPR 2017. Retrieved from https://ec.europa.eu/digital-single-market/en/news/europes-digital-progressreport-2017

European Commission (2018). Digital Education Action Plan. Retrieved from https://eurlex.europa.eu/legal-content/EN/TXT/?uri=COM:2018:22:FIN

Facione, P. (1990). Critical thinking: A statement of expert consensus for purposes of educational assessment and instruction (The Delphi Report). Millbrae, CA: California Academic Press.

Falk, J. H., Heimlich, J., \& Bronnenkant, K. (2008). Using identity-related visit motivations as a tool for understanding adult zoo and aquarium visitors' meaningmaking. Curator: The Museum Journal, 51(1), 55-79. doi:10.1111/j.21516952.2008.tb00294.x 
Not, E., \& Petrelli, D. (2018). Blending customisation, context-awareness and adaptivity for personalised tangible interaction in cultural heritage. International Journal of Human-Computer Studies, 114, 3-19. doi:10.1016/j.ijhcs.2018.01.001

OECD (2018). Education at a Glance: OECD Indicators. Paris: OECD Publishing.

Poce, A., Agrusti, F., \& Re, M. R. (2015). Sviluppo di uno strumento di valutazione delle risorse aperte (Oers). Cadmo, 2, 81-98. doi:10.3280/CAD2015-002008

Poce, A., \& Iovine, A. (2015). From cultural to socio-economic capital: lessons from a postgraduate course in 'standards for museum education'. In H. Chatterjee, \& L. Hannan (Eds), Engaging the Senses: Object-Based Learning in Higher Education (pp. 177-191). London: Routledge.

Poce, A. (2017). Verba Sequentur. Pensiero e scrittura per uno sviluppo critico delle competenze nella scuola secondaria. Milano: Franco Angeli.

Poce, A. (2019). Information and data literacy skills development in Creative Industries Adult Education: the Digiculture project. PEDAGOGIA OGGI, 17(2), 184-201. doi: 10.7346/PO-022019-12 